\title{
Fluorescence and Reflectance Spectroscopy for Early Detection of Different Mycorrhized Plantain Plants
}

\author{
Wilfried G. Dibi ${ }^{1,2}$, Beaulys Fotso ${ }^{3}$, Casimir Y. Brou ${ }^{3}$, Jérémie T. Zoueu ${ }^{1}$, Adolphe Zeze $^{3} \&$ Jocelyne Bosson $^{2}$ \\ ${ }^{1}$ Laboratoire d'Instrumentation Image et Spectroscopie, Unité Mixte de Recherche et d'Innovation en \\ Electronique et Electricité Appliquée, Ecole Supérieure d'Industrie, Institut National Polytechnique Houphouët \\ Boigny BP 1093 ESI Yamoussoukro, Côte d'Ivoire \\ ${ }^{2}$ Laboratoire de Physique Fondamentale et Appliquée, Unité de Formation et de Recherche des Sciences \\ Fondamentales et Appliquées, Université Nangui Abrogoua, 02 BP 801 Abidjan 02, Côte d'Ivoire \\ ${ }^{3}$ Laboratoire des Biotechnologies Végétale et Microbienne, Unité Mixte de Recherche et d'Innovation en Sciences \\ Agronomiques et Génie Rural, Ecole Supérieure d'Agronomie, Institut National Polytechnique \\ Houphouët-Boigny BP 1313 ESA Yamoussoukro, Côte d'Ivoire \\ Correspondence: Jérémie T. Zoueu, Laboratoire d'Instrumentation Image et Spectroscopie, Institut National \\ Polytechnique Felix Houphouët-Boigny Yamoussoukro, Cote d'Ivoire. Tel: 225-3064-6684. E-mail: \\ Jeremie.zoueu@inphb.edu.ci
}

Received: March 4, 2016 Accepted: March 17, 2016 Online Published: April 19, 2016

doi:10.5539/apr.v8n3p17 URL: http://dx.doi.org/10.5539/apr.v8n3p17

\begin{abstract}
Sustainable agriculture with use of Arbuscular Mycorrhizal Fungi (AMF) is an emerging farm management that improves crops nutrient and water use efficiency. Decision making on the effect of AMF is still dependent on agronomic diagnosis which is long, tedious, expensive and destructive. This study demonstrates the applicability of proximal fluorescence and reflectance spectroscopy for evaluating and detecting at early stage distinct types of mycorrhized plantain from two cultivars (Musa paradisiaca).

Visible-near infrared (400-1000 $\mathrm{nm}$ ) reflectance and fluorescence data were collected from control and three levels mycorrhized plants designed in randomized and complete block under greenhouse conditions. Two spectral measurements at a week interval were performed on plant leaves by using an USB spectrometer mounted with an Arduino-based LED driver clip.

A new normalized reflectance water NWI5 index shows with Datt5 alone highly significant differences at $\mathrm{P}<0.001$ respectively for Orishele and fhia21 cultivars. dNIRmin920_980, NDVI3 and GI reflectance index are significant at $\mathrm{P}<0.01$. Seven other reflectance and 3 fluorescence indices ANTH, FRF_R and NBI_R are significant at $\mathrm{P}<0.05$. The two first principal components for each cultivar spectral features explaining $94.1 \%$ of variance were used to build predictive classification models. LogitBoost algorithm indicates accuracy of $90.27 \%$ on stratified cross-validation and $87.5 \%$ on test split. Our results confirm that fluorescence and reflectance spectroscopy is a valuable tool for early assessment of mycorrhization success rate evaluation and pattern recognition. They also show promise for the development of non-destructive and cost-effective detectors in monitoring crops under biofertilizers with arbuscular mycorrhizae.
\end{abstract}

Keywords: classification, fluorescence and reflectance spectroscopy, LogitBoost algorithm, mycorrhized plantain plants.

\section{Introduction}

Agricultural remote sensing has gained great importance in sustainable and intensification farming management. It generates digital data from sensors that help in reducing the risk and minimize damage of inappropriate fertilization. Indeed, low or excessive uses of chemical fertilizers can have high adverse impact on the environment and grain production system. Unused nitrogen released to the environment can have detrimental effects (Cameron, Di, \& Moir, 2013). Large application of phosphate fertilizers and by-products has been practiced on arable lands, to improve crop production, induced soil nutrients deficiency, and increasing the levels of available S and P (Kassir, 2014). In the increasing demand of environmental sustainability, more attention of agricultural scientific community is being turned on biofertilizers particularly Arbuscular Mycorrhizal Fungi 
(AMF) (Weber, 2014; Sahraoui, 2013). Thus investigating the potential output of such biological microorganisms on crops with use of remote sensing tools is highly relevant.

Controlled endomycorrhization is a current problem that stayed long time ago in agriculture, horticulture and arboriculture (Gianinazzi, 1981). It was recently reported that diversity of plant response to mycorrhizal symbiosis essentially depends on isolates spores of species, soil fertility and environmental culture conditions (Garbaye, 2013). Optical sensing systems are potential and suitable tools for assessing mycorrhization success rate since they gather information on plant response, rather than costly, time-consuming, and destructive laboratory analyses. In this field, many efforts are done with various acquisitions sensing system and several spectral features developed (Mulla, 2013; Pinheiro \& Gusmo Dos Anjos., 2014) .However, there is an apparent lack of study in remote sensing crop investigation with arbuscular mycorrhizae. New spectral indices that simultaneously allow assessment of multiple crops characteristic and reveal better understanding of plant molecular mechanism could be retrieved.

An incident photosynthetically active radiation (PAR) interaction with plant leaves induced various spectral response in absorbance, reflectance and transmittance. Reflectance expresses light use efficiency of plant (Barton \& North, 2001). Reflectance properties of leaves are determined by the concentration of chlorophyll, other pigments (carotenoids, xanthophylls and anthocyanins) and absorbing biochemicals in the visible (400-700 nm) wavelength region, by mesophyll structure in the near infrared $(700-1200 \mathrm{~nm})$ region and by amount of water in the near infrared (950-970 nm) and in the middle infrared (1200-2400 nm) region (Peñuelas, 1998). When a fluorescent molecule absorbs the energy of a given wavelength, a part of it is dissipated by light emission at longer wavelengths within a very short time. This small but variable amount of energy loss is known as the fluorescence emission which is fingerprint of leaf photosynthetic activity. Coupling the measurements of reflectance and fluorescence with high spectral resolution has been suggested for improving crop productivity evaluation (Baret, Guyot, \& Major, 1988), stress diagnosis (Lichtenthaler, Wenzel, \& Buschmann, 2006) and nutrient diagnosis (Belanger, Viau, Samson, \& Chamberland, 2005). Decades of research in vegetation reflectance and fluorescence-based methods has gone into finding multiple indices precisely related to several leaf pigments, stresses, and mineral content. Combination of fluorescence and reflectance could reveal some functional properties of AMF in crop production particularly in plantain and banana case where their effects have been studied in recent Africa's agricultural researches (Nwaga et al., 2011; Gaidashova et al., 2013; Jefwa et al., 2013).

Multi-class classification in crops remote sensing is performed by means of data mining techniques. In this approach, several methods of machine learning have been utilized for plant characteristics detection. Support Vector Machine are important advanced techniques intensively used (Mountrakis \& Ogole, 2011; Moshou, Pantazi, Kateris, \& Gravalos, 2014). Others efficient tools are concerned with fuzzy logic, neural network and extreme learning machine (Moreno, Corona, Lendass, Graña, \& Galvão 2014; Murmu \& Biswas, 2015; Cvetković, Stojanović, \& Nicolić, 2015).The boosting meta-algorithm is relatively new, efficient, simple, and easy to manipulate additive modeling technique that can use potentially any weak learner available. LogitBoost is another variant of the boosting algorithm that performs additive logistic regression (Friedman, Hastie, \& Tibshirani, 2000) and has shown better performance than many other machine learning algorithm especially in protein data structure classification (Krishnaraj \& Reddy, 2009). At present, new improvements of this algorithm are proposed (Kanamori \& Takenouchi, 2013; Sun, Reid \& Zhou, 2014).

In this study, we aimed at evaluating early detection of mycorrhized plantain using active fluorescence and reflectance spectrometry. The specific objectives were to (1) identify the most significant fluorescence and reflectance vegetation indices explaining mycorrhizae effects on plantains and to (2) build predictive classification model for each mycorrhizal treatment using spectral features discovered.

\section{Material and methods}

\subsection{Plant Material and Experimental Design}

The experiment was conducted under greenhouse conditions at the Laboratoire des Biotechnologies Végétale et Microbienne in National Polytechnic Houphouet-Boigny Institute of Yamoussoukro (Côte d'Ivoire). Two plantain varieties namely Orishele (sensitive to water stress) and Fhia 21 (tolerant to water stress) were cultivated in pots containing sterilized substrate composed of loam and sand. The plants were inoculated with a mycorrhizal morphotype of Glomus (T1), a complex of spores from the rhizosphere of plantain in Bouaflé (T2) and another complex of spores from the rhizosphere of plantain in Azaguié (T3). All treatments including control plants without any mycorrhizae (T0) were split into a randomized complete block design consisting of three replicates per treatment in each of the three blocks. 


\subsection{Formulation and Preparation of Inoculum}

Spores are extracted at the Laboratoire des Biotechnologies Végétale et Microbienne in National Polytechnic Houphouet-Boigny Institute of Yamoussoukro (Côte d'Ivoire) according to the method described by Gerdemann $\&$ Nicholson (1963). They were disinfected using bleach $2 \%$ and $0.2 \%$ streptomycin. The banana suckers were firstly cleaned, washed and acclimated in coco peat and then inoculated with these spores at 150 spores per pot.

\subsection{Optical Instrumentation and Spectral Measurements}

A hand-held clip LEDs was built in our laboratory and mounted with USB4000 spectrometer Ocean Optics for acquiring fluorescence and reflectance spectra on the upper leaf surface. The spectrometer can collect data in the $350-1000 \mathrm{~nm}$ spectral region, with a sampling interval of $0.22 \mathrm{~nm}$. Three Light-emitting-diodes excited the fluorescence at $375 \mathrm{~nm}$ (UV), $520 \mathrm{~nm}$ (green) and $630 \mathrm{~nm}$ (red) while the emitted fluorescence light was detected in the red (RF: 680-690 nm) and far-red (FRF: 720-755 nm) spectral regions using a low-pass filter at $650 \mathrm{~nm}$. A white LED emitting $(400-700 \mathrm{~nm})$ was utilized for reflectance measurement. All four LEDs were controlled using the computer and Arduino, a cost effective, open source and easy programmable microcontroller board (Arduino - Home). Reflectance spectra were carried out after comparing with a 99\% white reflectance standard (Labsphere $\AA$, Edmund Optics Inc. — 101 East Gloucester Pike, Barrington, NJ 080071380 USA). After three scans, an average spectrum is recorded using SpectraSuite ${ }^{\circledR}$ Software. Spectra acquisitions occurred between 29 November and 06 December 2014 with experimental setup showed in Figure 1.

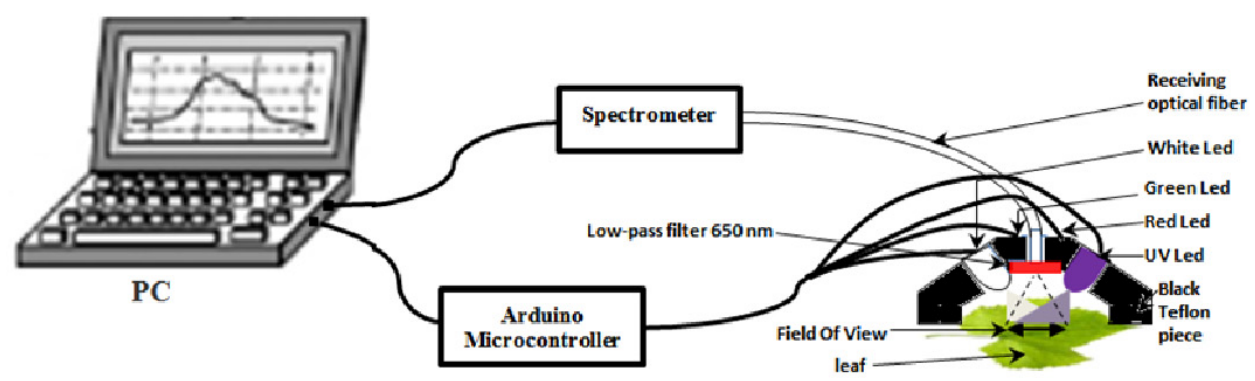

Figure 1. Schematic drawing of the experimental setup used for spectra acquisition

\subsection{Spectra Preprocessing and Normalization}

The spectra dataset recorded are firstly filtered using Gaussian normal probability density function in matlab. Then, each spectrum is standardized by its own average and standard deviation for baseline and quantity correction (Barnes, Dhanoa \& Lister., 1993). Finally, in the hypothesis that the number of photon at any wavelength should be constant across shots, we proceeded to $\mathrm{min} / \mathrm{max}$ normalization. Each spectrum is normalized to have a minimum value of 0 and a maximum value of 1 . This normalization was accomplished according the formula:

$$
x_{\text {norm }}=\frac{\left(x-\min _{i} x_{i}\right)}{\left(\max _{i} x_{i}-\min _{i} x_{i}\right)}
$$

\subsection{Fluorescence and Reflectance Indices Calculation}

Vegetation indices are widespread in remote sensing scientific literature. A database composed of 18 fluorescence and 90 reflectance indices were implemented in matlab for spectra features calculation. We tried to extend to almost reviewed vegetation index at leaf and canopy level for enabling maximum crop characteristic detection. These indexes are also supplemented with our proposed one.

\subsection{Statistical Analysis}

\subsubsection{One-Way Variance Analysis with Step-Down Dunnett Post Hoc Test}

ANalysis Of VAriance (often referred to as ANOVA) is a technique for analyzing the way in which the mean of a variable is affected by different types and combinations of factors. One-way analysis of variance is the simplest form in which we are interested in comparing the dependent variable means of two or more groups defined by a categorical grouping factor (Bewick, Cheek, \& Ball, 2004). Analysis of variance is initially performed on two groups (control and all mycorrhized plants together) then on four groups (control and each of three mycorrhizal treatments). In order to understand subgroup differences among the different experimental and control group, we 
chose to perform step-down Dunnett test which is more suitable and powerful (Bretz, Hothorn \& Westfall, 2010). R software version 3.1.2 (R Core Team, 2014) was used for ANOVA analysis and for multiple comparisons.

\subsubsection{Principal Components and Vegetation Index Correlation Analysis}

Principal components analysis (PCA) is a data reduction technique that transforms a larger number of correlated variables into a much smaller set of uncorrelated variables called principal components. The weights used to form the linear composites are chosen to maximize the variance each principal component accounts for, while keeping the components uncorrelated. We generated principal components for each cultivar with their respective significant vegetation indices.

Correlation analysis was also used for establishing relationship between new indice developed and existing ones.

\subsubsection{LogitBoost Classifier}

Boosting implements forward stagewise additive modeling. This class of algorithms starts with an empty ensemble and incorporates new members sequentially. At each stage the model that maximizes the predictive performance of the ensemble as a whole is added, without altering those already in the ensemble. Additive logistic regression use similar adaptation by modifying the forward stagewise modeling method (Witten, Frank, \& Hall, 2011).

For K-class classification $(K \geq 2)$, consider an Nexample training set $\left\{x_{i}, y_{i}\right\}_{i=1}^{N}$ where $x_{i}$ denotes a feature value and $y_{i} \in\{1, \ldots, K\}$ denotes a class label. Class probabilities conditioned on $x$ denoted by $p=\left(p_{1}, \ldots, p_{K}\right)^{T}$ are learned from the training set. For a test example with known $x$ and unknown $y$, we predict a class label by using the Bayes rule: $y=\operatorname{argmax}_{k} p_{k}, k=1, \ldots, K$.

Instead of learning the class probability directly, one learns its "proxy" $F=\left(F_{1}, \ldots, F_{K}\right)^{T}$ given by the so-called Logit link function:

$$
p_{k}=\frac{\exp \left(F_{k}\right)}{\sum_{j=1}^{K} \exp \left(F_{j}\right)}
$$

with the constraint $\sum_{k=1}^{K} F_{k}$ (Friedman et al., 2000). For simplicity and without confusion, we hereafter omit the dependence on $x$ for $F$ and for other related variables.

The $F$ is obtained by minimizing a target function on training data:

$$
\text { Loss }=\sum_{i=1}^{N} L\left(y_{i} x_{i}\right)
$$

where $F_{i}$ is shorthand for $F\left(x_{i}\right)$ and $L\left(y_{i}, F_{i}\right)$ is the Logit loss for a single training example:

$$
L\left(y_{i}, F_{i}\right)=-\sum_{k=1}^{K} r_{i k} \log p_{i k}
$$

Where $r_{i k}=1$ if $y_{i}=k$ and $o$ otherwise. The probability $p_{i k}$ is connected to $F_{i k}$ via (2).

To make the optimization of (3) feasible, a model is needed to describe how $F$ depends on $x$. For example, linear model $F=W^{T} x$ is used in traditional Logit regression, while Generalized Additive Model is adopted in LogitBoost:

$$
F(x)=\sum_{m=1}^{M} f_{m}(x),
$$

where each $f_{m}(x)$, a $K$ dimensional sum-to-zero vector, is learned by greedy stage-wise optimization. That is, at each iteration $f_{m}(x)$ is added only based on $F=\sum_{j=1}^{m-1} f_{j}$. Formally,

$$
\begin{gathered}
f_{m}(x)=\operatorname{argmin}_{f} \sum_{i=1}^{N} L\left(y_{i}, F_{i}+f\left(x_{i}\right)\right), \\
\text { s.t. } \sum f_{k}\left(x_{i}\right)=0, i=1, \ldots, N,
\end{gathered}
$$

This procedure repeats $M$ times with initial condition $F=0$. Owing to its iterative nature, we only need to know how to solve (6) in order to implement the optimization (Sun et al., 2014).

Models were performed in WEKA 3.6.13 software Explorer interface (Hall et al., 2009). They were built separately for each cultivar using their own significant fluorescence and reflectance indices according to ANOVA results. The four output classes used in the analysis were T0, T1, T2 and T3 distributed on 72 observations in each model. In holdout evaluation, the data were randomly separated into training and test datasets such that $66 \%$ of the data was utilized for training the classifier model; while $33 \%$ of the data was used for testing the developed classifier model. In order to mitigate any bias by the particular sample chosen for holdout, we performed a tenfold stratified cross-validation. The outcomes metrics are automatically generated in WEKA. Two-class outcomes are presented in figure 2 for interpretation needs. 


\begin{tabular}{|c|c|c|c|c|}
\hline & \multicolumn{2}{|c|}{ Predicted Class } & \multirow{5}{*}{$\begin{array}{l}\text { TP rate }(\%)=\frac{T P}{T P+F N} \times 100 \\
\text { FP rate }(\%)=\frac{F P}{\mathrm{FP}+\mathrm{TN}} \times 100 \\
\text { Precision }(\%)=\frac{\mathrm{TP}}{\mathrm{TP}+\mathrm{FP}} \times 100 \\
\text { Recall }(\%)=\frac{\mathrm{TP}}{\mathrm{TP}+\mathrm{FN}} \times 100\end{array}$} \\
\hline & & yes & no & \\
\hline \multirow{3}{*}{$\frac{\tilde{c}}{\frac{\pi}{U}}$} & yes & true positive (TP) & false negative (FN) & \\
\hline & & & & \\
\hline & no & false positive (FP) & true negative (TN) & \\
\hline
\end{tabular}

Figure 2. Confusion matrix and associated classification measures in two-class case

\section{Results and Discussion}

\subsection{Data Representation after Preprocessing and Normalization}

Fluorescence spectra using UV (375 nm), Green $(520 \mathrm{~nm})$ and Red $(630 \mathrm{~nm})$ essentially show two peaks in red band (685- 690nm) and far-red band (735-740 nm) known as chlorophyll a fluorescence (Buschmann Langsdorf \& Lichtenhaler, 2008; Misra \& Singh, 2012). Intensity at these two bands vary when using an UV (375 nm) or Green $(520 \mathrm{~nm})$ light because of respective absorption at these wavelengths of flavonols (Cerovic et al., 2002) and anthocyanins pigments (Agati et al., 2005). Analysis of reflectance curve presents a deep through in $850-1000 \mathrm{~nm}$ band and two others at 778-788 $\mathrm{nm}$ and $834-840 \mathrm{~nm}$ bands. These observations may be attributed to water absorption.
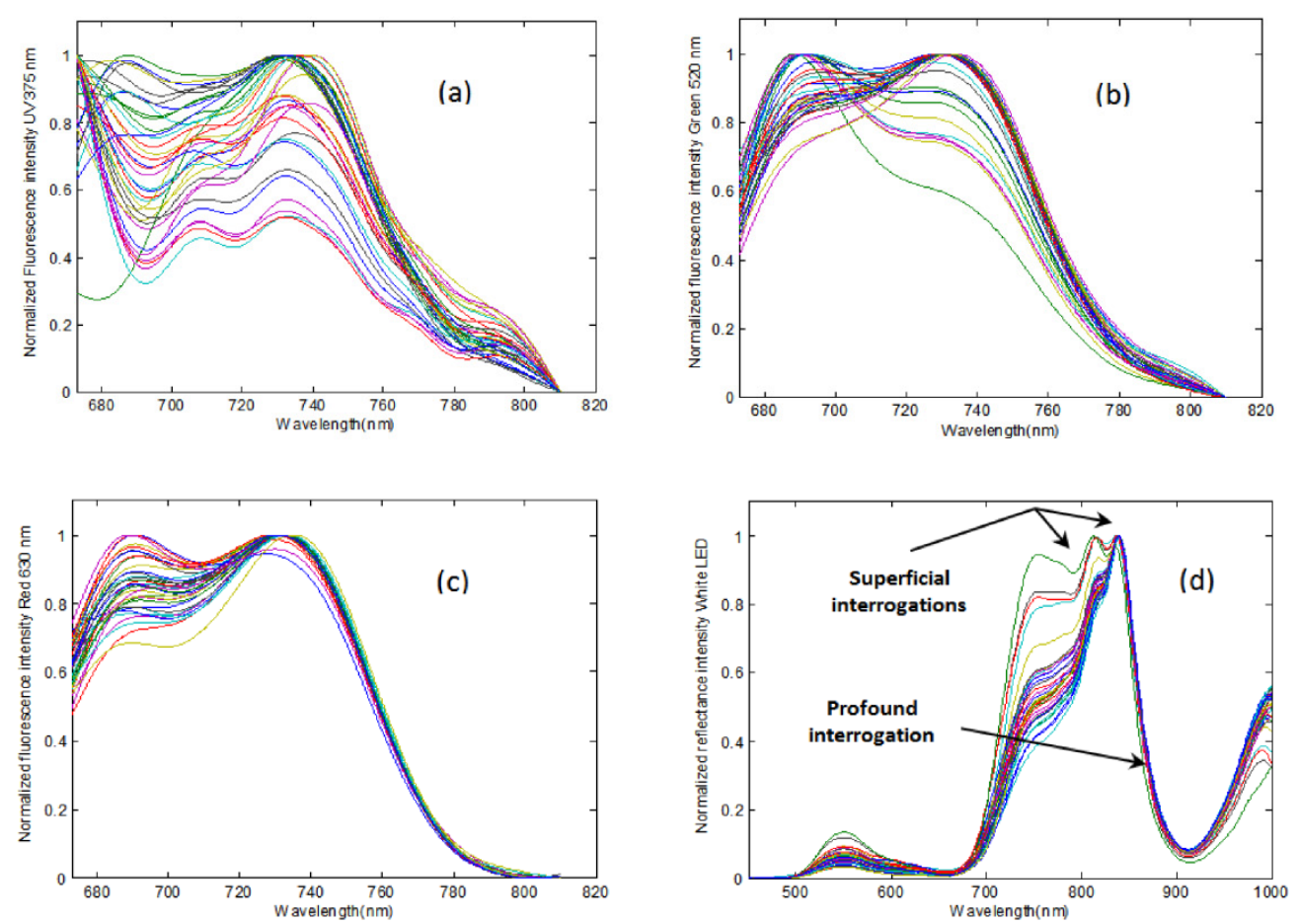

Figure 3. Normalized fluorescence spectra using excitation Led source at $375 \mathrm{~nm}$ (a), excitation Led source at $520 \mathrm{~nm}$ (b), excitation Led source at $630 \mathrm{~nm}$ (c) and normalized reflectance spectra using white light Led source 400-700 $\mathrm{nm}(\mathrm{d})$ in experimental setup 


\subsection{Spectral Responses to Plantain Mycorrhizal Treatment}

Analysis of variance of 108 vegetation indexes reveals 3 significant fluorescence indices and 12 significant indices for reflectance spectra. ANOVA results in Table 1 and 2 show that differences between control and each of three mycorrhizal treatments are revealed by reflectance indexes. Two reflectance indexes are highly significant $(\mathrm{P}<0.001)$ : Datt5 for Fhia 21 cultivar and the new index NWI5 for Orishele cultivar.

Table 1. Effect of AM fungal inoculation on calculated vegetation indexes of plantain cultivar Fhia 21 under greenhouse conditions

\begin{tabular}{|c|c|c|c|c|c|c|c|c|c|c|c|c|}
\hline \multirow[t]{3}{*}{ ANOVA } & \multicolumn{12}{|c|}{ Vegetation Index } \\
\hline & \multicolumn{2}{|c|}{ Fluorescence } & \multicolumn{10}{|c|}{ Reflectance } \\
\hline & ANTH & FRF_R & Carter5 & Datt5 & SR5 & GI & NDVI3 & NWI & NWI4 & NWI5 & $\begin{array}{l}\text { dNIRMin } \\
920 \_980\end{array}$ & $\min 950 \_970$ \\
\hline $\begin{array}{l}\text { All } \\
\text { mycorrhized } \\
\text { treatment }\end{array}$ & * & $*$ & NS & $* *$ & NS & $* *$ & $* *$ & NS & NS & $*$ & * & * \\
\hline $\begin{array}{l}\text { Three level } \\
\text { mycorrhized } \\
\text { treatment }\end{array}$ & NS & NS & $*$ & $* * *$ & $*$ & $* *$ & $* *$ & * & $*$ & $* *$ & NS & * \\
\hline
\end{tabular}

Significance code: $*$ Significant at $0.05,{ }^{* *}$ significant at $0.01,{ }^{* *}$ significant at 0.001, NS Not significant

Table 2. Effect of AM fungal inoculation on calculated vegetation indexes of plantain cultivar Orishele under greenhouse conditions

\begin{tabular}{|c|c|c|c|c|c|c|c|}
\hline \multirow[b]{3}{*}{ ANOVA } & \multicolumn{7}{|c|}{ Vegetation Indexes } \\
\hline & \multirow{2}{*}{$\frac{\text { Fluorescence }}{\text { NBI_R }}$} & \multicolumn{6}{|c|}{ Reflectance } \\
\hline & & DPI & RatiodRE_703 & NWI & NWI5 & dNIRmin920_980 & $\min 950 \_970$ \\
\hline All & & & & & & & \\
\hline $\begin{array}{l}\text { mycorrhized } \\
\text { treatment }\end{array}$ & * & $*$ & NS & $*$ & $* *$ & $* *$ & $*$ \\
\hline $\begin{array}{l}\text { Three level } \\
\text { mycorrhized } \\
\text { treatment }\end{array}$ & NS & $*$ & - & $*$ & $* * *$ & 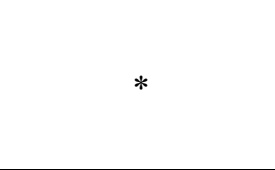 & $*$ \\
\hline
\end{tabular}

Table 3 gives us an overview on their definition and relationship with bioparameters. From most to least importance order, these spectral features are related to water content (NWI, NWI5, NWI4, dNIRMin920_980, min950_970), chlorophyll content (Datt5, NDVI3, SR5, and RatiodRE_703), anthocyanin content (ANTH), foliar density (FRF_R), nitrogen content (NBI_R), photosynthetic activity (DPI) and leaf area index (GI).

As expected, most of these spectral features appear to be relevant in plantain mycorrhization studies. On the one hand, we can see that indices linked to water content appear with great occurrence in both varieties: NWI, NWI4, NWI5, dNIRmin920_980, min950_970. These water-based indexes demonstrate that mycorrhized plantains have better water content in comparison to control. This result agrees with Nwaga et al. (2011) study which has shown good correlation between water use efficiency and drought tolerance of mycorrhized plantains. As an example, Orishele water content indices given in Figure 4 show that water-based indexes means for all mycorrhized classes are higher than control ones. 
Table 3. Overview of significant fluorescence and reflectance indexes in Fhia 21 and Orishele plantain cultivars

\begin{tabular}{|c|c|c|c|}
\hline Vegetation index & Related to & Equation & Reference \\
\hline \multicolumn{4}{|l|}{ Fluorescence indexes } \\
\hline Anthocyanin (ANTH) & $\begin{array}{l}\text { Anthocyanin } \\
\text { content }\end{array}$ & $\log \left(F R F_{-} R / F R F_{-} G\right)$ & Agati et al. (2005) \\
\hline $\begin{array}{l}\text { Far-Red Fluorescence } \\
\text { with Red light (FRF_R) }\end{array}$ & $\begin{array}{l}\text { Foliar density, } \\
\text { leaf strength }\end{array}$ & $F R F_{-} R$ & $\begin{array}{l}\text { Bramley et al. } \\
\text { (2011) }\end{array}$ \\
\hline $\begin{array}{l}\text { Red Nitrogen Balance } \\
\text { Index (NBI_R) }\end{array}$ & $\begin{array}{l}\text { Nitrogen } \\
\text { content }\end{array}$ & $\log \left(F R F_{-} U V / F R F_{-} R\right)$ & $\begin{array}{l}\text { Cartelat et al. } \\
(2005)\end{array}$ \\
\hline \multicolumn{4}{|l|}{ Reflectance indexes } \\
\hline SR5 & Chlorophyll a & $R_{675} / R_{700}$ & $\begin{array}{l}\text { Chappelle, Kim \& } \\
\text { McMurtrey }\end{array}$ \\
\hline Datt5 & Chlorophyll b & $R_{672} / R_{550}$ & Datt (1998) \\
\hline $\begin{array}{l}\text { Normalized Difference } \\
\text { Vegetation Index (NDVI3) }\end{array}$ & $\begin{array}{l}\text { Chlorophyll } \\
\text { total }\end{array}$ & $\left(R_{682}-R_{553}\right) /\left(R_{682}+R_{553}\right)$ & $\begin{array}{l}\text { Gandia, Fernandez, } \\
\text { Garcia \& Moreno } \\
(2004)\end{array}$ \\
\hline $\begin{array}{l}\text { Ratio of first derivative } \\
\text { maximum value in red-edge with } \\
\text { reflectance one at } 703 \mathrm{~nm} \\
\text { (RatiodRE_703) }\end{array}$ & $\begin{array}{l}\text { Chlorophyll, } \\
\text { Water content }\end{array}$ & $\max D_{680-780} / D_{703}$ & $\begin{array}{l}\text { Filella \& Peñuelas } \\
\text { (1994) }\end{array}$ \\
\hline Greenness Index (GI) & $\begin{array}{l}\text { Chlorophyll, } \\
\text { Leaf Area Index }\end{array}$ & $R_{554} / R_{677}$ & $\begin{array}{l}\text { Smith, Adams, } \\
\text { Stephen \& Hick } \\
(1995)\end{array}$ \\
\hline Carter5 & Stress & $R_{695} / R_{670}$ & Carter (1994) \\
\hline Double Peak Index (DPI) & $\begin{array}{l}\text { Photosynthetic } \\
\text { activity }\end{array}$ & $\left(D_{688} \times D_{710}\right) / D_{697}^{2}$ & $\begin{array}{l}\text { Zarco-Tejada, } \\
\text { Pushnik, } \\
\text { Dobrowski \& Ustin } \\
(2003)\end{array}$ \\
\hline $\begin{array}{l}\text { Normalized Water Index } \\
(\mathrm{NWI})\end{array}$ & Water content & $\left(R_{970}-R_{900}\right) /\left(R_{970}+R_{900}\right)$ & $\begin{array}{l}\text { Barbar et al. } \\
(2006)\end{array}$ \\
\hline $\begin{array}{l}\text { Normalized Water Index } 4 \\
\text { (NWI4) }\end{array}$ & Water content & $\left(R_{970}-R_{920}\right) /\left(R_{970}+R_{920}\right)$ & Prasad et al. (2007) \\
\hline $\begin{array}{l}\text { Normalized Water Index } 5 \\
\text { (NWI5) }\end{array}$ & Water content & $\frac{\left(\min R_{778-788}-\min R_{834-840}\right)}{\left(\min _{778-788}+\min R_{834-840}\right)}$ & In this study \\
\hline $\begin{array}{l}\text { Minimum value of the first } \\
\text { derivative in 920-980 range } \\
\text { (dNIRMin920_980) }\end{array}$ & Water content & $\min D_{920-980}$ & $\begin{array}{l}\text { Peñuelas, Fillela, } \\
\text { Biel , Serrano \& } \\
\text { Salvé(1993) }\end{array}$ \\
\hline $\begin{array}{l}\text { Minimum value in 950-970 } \\
\text { range (min950_970) }\end{array}$ & Water content & $\min R_{950-970}$ & $\begin{array}{l}\text { Peñuelas, Fillela, } \\
\text { Biel, Serrano \& } \\
\text { Salvé(1993) }\end{array}$ \\
\hline
\end{tabular}



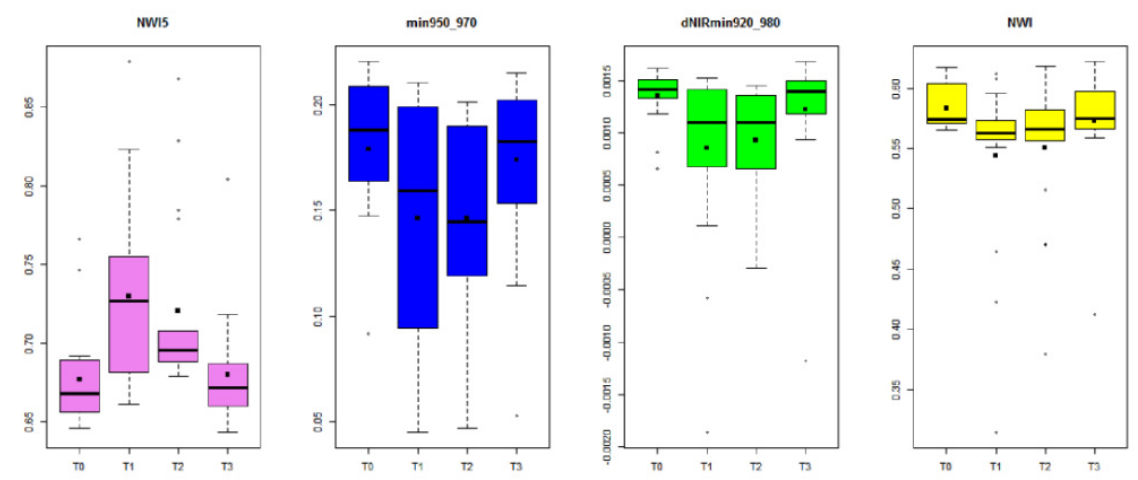

Figure 4. Boxplots of water-based vegetation indices (NWI5, min950_970, dNIRmin920_980 and NWI) for each treatment group for Orishele variety. Means are shown by fat dots, boxes indicate median and interquartile range, with vertical lines depicting the range. Dots outside vertical range are outliers' data

As suggested from the reflectance curve analysis, we computed a new normalized water index NWI5. This index shows significant differences between treatments for both varieties and is strongly correlated with leaf water content as it appears in correlation matrices (Table 4 and 5) particularly with water index content dNIRmin920_980 and min950_970 $(-0.84<\mathrm{r}<-0.88)$. Therefore this parameter may stand as an indicator of water status. The negative correlation with the two literature indexes mentioned above suggests that water content in leaf is high when NW5 is high. Indeed dNIRmin920_980 and min950_970 are negatively correlated with relative water content. In addition, NWI5 presents more significance in Orishele variety than in Fhia 21 because Orishele is more sensitive to water stress. As a result, NWI5 could better track plant water stress sensitivity.

Table 4. Pearson correlation coefficients (all with $\mathrm{p}$ value $<0.01$ ) for water content reflectance indexes of Fhia 21 variety

\begin{tabular}{lccccc}
\hline Reflectance indexes & dNIRmin920_980 & min950_970 & NWI4 & NWI5 & NWI \\
\hline dNIRmin920_980 & - & & & & \\
min950_970 & 0.842 & - & & & \\
NWI4 & 0.572 & 0.508 & - & & \\
NWI5 & -0.843 & -0.879 & -0.511 & - & \\
NWI & 0.445 & 0.358 & -0.860 & -0.452 & - \\
\hline
\end{tabular}

Table 5. Pearson correlation coefficients (all with $p$ value $<0.01$ ) for water content reflectance indexes of Orishele variety

\begin{tabular}{lllll}
\hline Reflectance indexes & dNIRmin920_980 & min950_970 & NWI5 & NWI \\
\hline dNIRmin920_980 & - & & & \\
min950_970 & 0.826 & - & & \\
NWI5 & -0.859 & -0.838 & - & \\
NWI & 0.780 & 0.559 & -0.754 & - \\
\hline
\end{tabular}

On the other hand, related works (Tropical Soil Biology and Fertility [TSBF], 2007; Declerck, Cevos, Devos, \& Plenchette, 1994) have reported that AMF improves nutrient uptake and growth of bananas particularly an enhancement of $\mathrm{P}$ uptake. In this context, our study provides additive information especially about mycorrhization effects on plantain nutrition, leaf pigment content and photosynthetic activity. Indeed, in variety Fhia 21, ANTH index which is negatively correlated with anthocyanin content as demonstrated by J. Baluja (2012), indicates that all mycorrhizal treatment induces an increase of anthocyanins. FRF_R index is related to 
foliar density. Bramley et al. (2011) showed that NDVI provided by GreenSeeker has a positive relationship with index FRF_R obtained using the Multiplex long distance to flowering when the vegetation is less developed. So we deduce low rate of chlorophyll content in Fhia 21 variety for mycorrhized plants. This is also illustrated in figure 5 by chlorophyll index (Datt5, SR5, NDVI3 and GI) and is due to higher anthocyanin content.
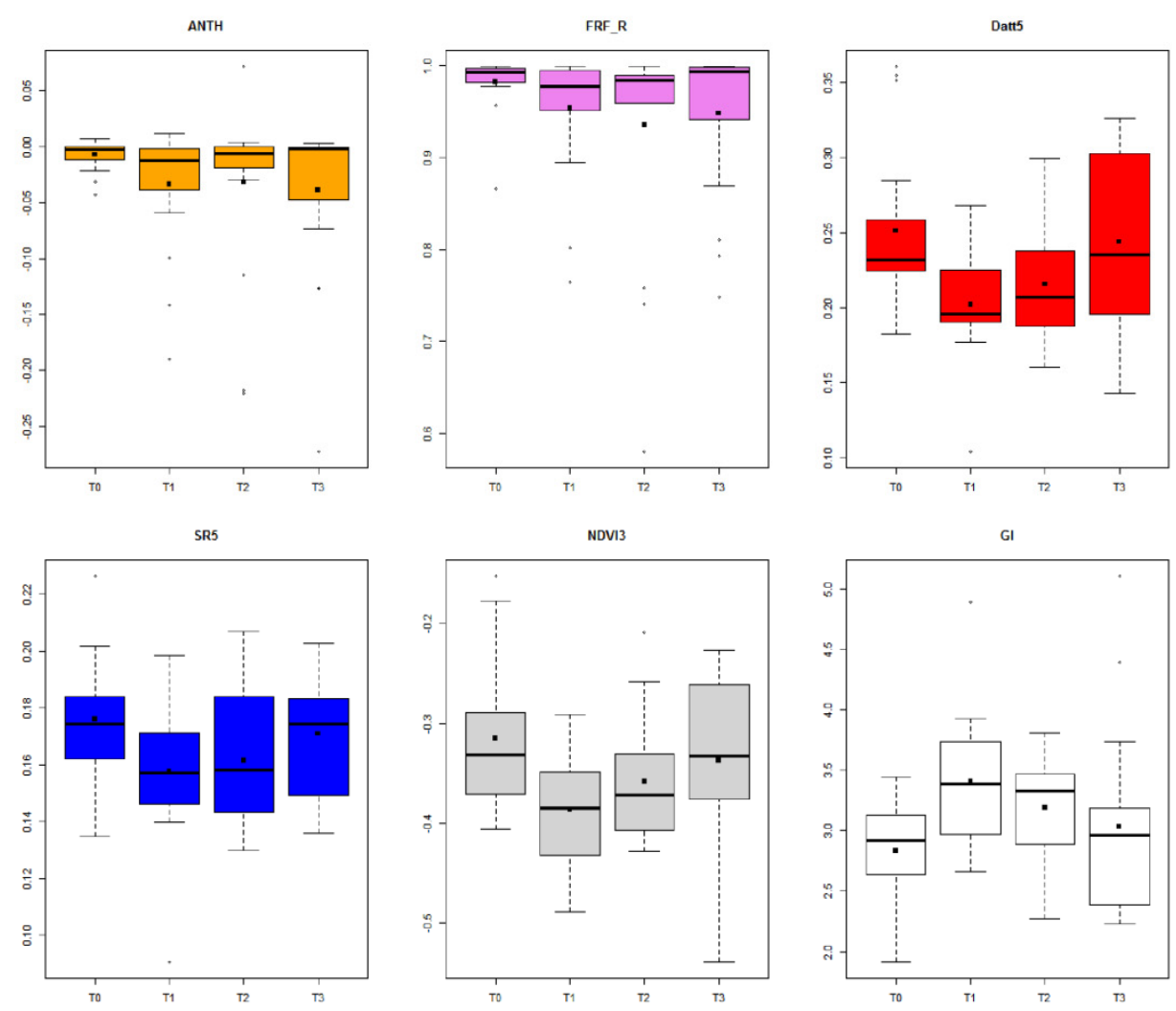

Figure 5. Boxplots of vegetation indices (ANTH, FRF_R, Datt5, SR5, NDVI3 and GI) for each treatment group for Orishele variety. Means are shown by fat dots; boxes indicate median and interquartile range, with vertical lines depicting the range. Dots outside vertical range are outliers' data

In Orishele variety, improved effects of mycorrhizae on chlorophyll content and photosynthetic activity appear and are respectively shown by higher value of red-edge spectral feature (RatiodRE 703) and double peak indice (DPI) in T1 and T2 mycorrhized treatments (Figure 6). Experience conducted by Zarco-Tejada et al (2003) have demonstrated that natural fluorescence emission is observable on the first derivative reflectance spectra as a double-peak feature in the $690-710 \mathrm{~nm}$ spectral region. DPI is capable for tracking natural steady-state fluorescence and is closely related to photosynthetic activity so that DPI is low when photosynthetic rates are high. Nethertheless, NBI_R boxplot means show that plants with inoculated mycorrhizae have low nitrogen content even if we can observe highest value of this index (1.3-1.51) for T1 treatment. NBI_R which is expressed by the ratio between epidermal phenolic compounds and chlorophyll is positively well correlated to the leaf N content (Agati, Foshi, Grossi \& Volterrani, 2015). Figure 6 illustrates distribution of vegetation indices (NBI_R, RatiodRE_703 and DPI) according to mycorrhizal treatments for Orishele variety.

Step-down Dunnett test helps us identifying the most effective mycorrhizal treatments in comparison to control. From multiple comparison analysis, only significant vegetation index with four groups in ANOVA are concerned. Results in Table 6 show clearly that for Fhia 21 cultivar treatment T1 is the best and then treatment T2 follows concerning with improvement of water content performance. Reflectance indexes in Table 7 indicate that treatment $\mathrm{T} 1$ and $\mathrm{T} 2$ are efficient with few precision about the first one and the second one according to step-down Dunnett statistical test. In both varieties, following indexes namely Carter5, GI, RatiodRE_703 and NWI5 were not able to discriminate mycorrhizal treatments with this test. In addition, treatment T3 is not at all significant. 

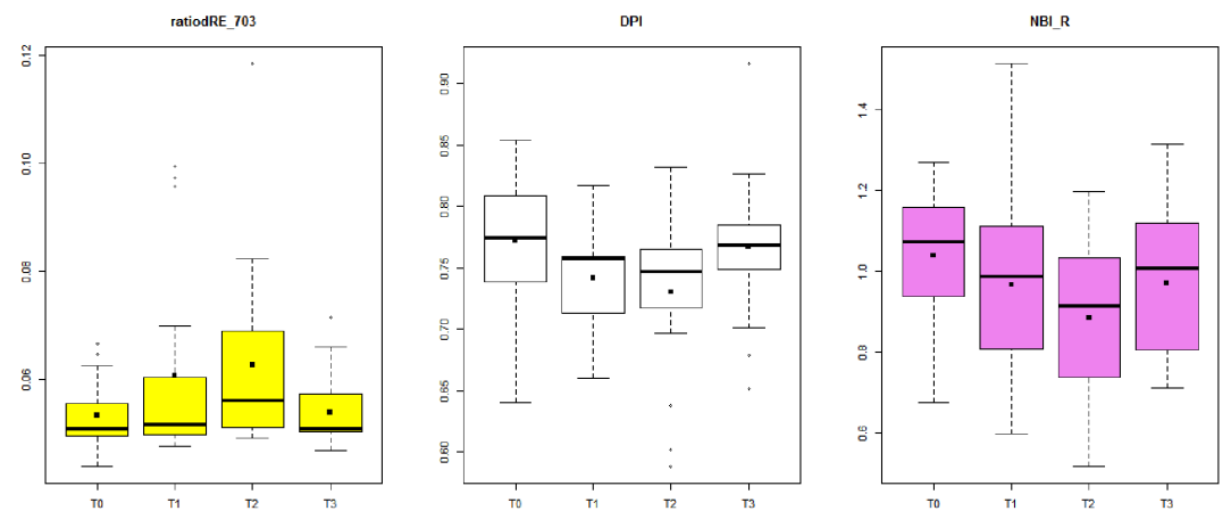

Figure 6. Boxplots of vegetation indices for each treatment group for Orishele variety (RatiodRE_703, NBI_R, and DPI). Means are shown by fat dots; boxes indicate median and interquartile range, with vertical lines depicting the range. Dots outside vertical range are outliers' data

Table 6. Multiple comparisons of means to a control of plantain cultivar Fhia 21 under greenhouse condition

\begin{tabular}{llllllllll}
\hline \multirow{2}{*}{$\begin{array}{l}\text { Mycorrhizal Treatment } \\
\text { vs control }\end{array}$} & \multicolumn{7}{c}{ Step-down Dunnett statistical significance } \\
\cline { 2 - 10 } & Carter5 & Datt5 & SR5 & GI & NDVI3 & NWI & NWI4 & NWI5 & min950_970 \\
\hline T1-T0 & NS & $* * *$ & $* *$ & NS & $* * *$ & $*$ & $* *$ & NS & $* *$ \\
T2-T0 & NS & $* *$ & $*$ & NS & $*$ & NS & NS & NS & $*$ \\
T3-T0 & NS & NS & NS & NS & NS & NS & NS & NS & NS \\
\hline
\end{tabular}

Significance code: $*$ Significant at $0.05,{ }^{* *}$ significant at $0.01,{ }^{* * *}$ significant at 0.001, NS Not significant.

Table 7 Multiple comparisons of means to a control of plantain cultivar Orishele under greenhouse conditions

\begin{tabular}{lllllll}
\hline & \multicolumn{5}{c}{ Step-down Dunnett statistical significance } \\
\cline { 2 - 7 } Mycorrhizal Treatment vs control & DPI & RatiodRE_703 & NWI & NWI5 & dNIRmin920_980 & min950_970 \\
\hline T1-T0 & $*$ & NS & $* *$ & NS & $* *$ & $* *$ \\
T2-T0 & $* *$ & NS & $*$ & NS & $* *$ & $* *$ \\
T3-T0 & NS & NS & NS & NS & NS & NS \\
\hline
\end{tabular}

Significance code: $*$ Significant at $0.05,{ }^{* *}$ significant at 0.01, NS Not significant.

Analysis of mycorrhizal effects on Fhia 21 and Orishele plantain cultivars leads us discovering a new water index as well as others relevant and varied fluorescence and reflectance indices. Spectral responses analysis of plants show essentially improved effects of mycorrhizae in water content for both varieties. Good effects are also revealed in anthocyanin, chlorophyll, photosynthetic activity and nitrogen content whose treatments T1 and T2 are mostly responsible for.

\subsection{LogitBoost Classification Evaluation}

In addition to finding most significant vegetation indexes and efficient mycorrhization treatment, additive logistic regression models are constructed to automatically predict specific class of a of mycorrhized plantain. Principal components used as variables input of models explains $99.47 \%$ of spectral features variability for Fhia 21 variety and $94.163 \%$ in Orishele one. The PC1 and PC2 extracted allow this as shown in Table 8.

Cross-validation gives us a first insight in classification performance. On total instances of 72 samples, $90.2778 \%$ are correctly classified while $9.7222 \%$ are misclassified for both varieties (Table 10). Detailed performance metrics are given in Table 9. Precisely, classification accuracy is higher for treatment without any mycorrhizae T0 (94.4 \%) than those with (88.9\%) in overall variety. In the mycorrhized classes treatment T3 has the best precision parameter $(94.1 \%$ ) because of its low FP Rate. In addition, we can explain higher value of recall in 
control class in such way that the FN samples are low. It is also notable to precise that mycorrhized treatment $\mathrm{T} 1$ and $\mathrm{T} 2$ present the same performance metrics.

Table 8. Principal components results

\begin{tabular}{ccc}
\hline Variety & Principal component & Variance explained (\%) \\
\hline \multirow{2}{*}{ Fhia 21} & PC1 & 89.44 \\
& PC1, PC2 & 99.47 \\
\hline \multirow{2}{*}{ Orishele } & PC1 & 80.04 \\
& PC1, PC2 & 94.163 \\
\hline
\end{tabular}

Table 9. Classification performance metrics of the LogitBoost classifier by class

\begin{tabular}{|c|c|c|c|c|c|c|}
\hline Variety & Evaluation method & Class & TP Rate & FP Rate & Precision & Recall \\
\hline \multirow{8}{*}{ Fhia 21} & \multirow{4}{*}{$\begin{array}{c}\text { Stratified } \\
\text { cross-validation }\end{array}$} & T0 & 94.4 & 3.70 & 89.5 & 94.4 \\
\hline & & $\mathrm{T} 1$ & 88.9 & 3.70 & 88.9 & 88.9 \\
\hline & & $\mathrm{T} 2$ & 88.9 & 3.70 & 88.9 & 88.9 \\
\hline & & $\mathrm{T} 3$ & 88.9 & 1.90 & 94.1 & 88.9 \\
\hline & \multirow{4}{*}{ Holdout } & T0 & 100 & 11.1 & 75.0 & 100 \\
\hline & & $\mathrm{T} 1$ & 60.0 & 0.00 & 100 & 60.0 \\
\hline & & $\mathrm{T} 2$ & 100 & 5.30 & 83.3 & 100 \\
\hline & & $\mathrm{T} 3$ & 87.5 & 0.00 & 100 & 87.5 \\
\hline \multirow{8}{*}{ Orishele } & \multirow{4}{*}{$\begin{array}{c}\text { Stratified } \\
\text { cross-validation }\end{array}$} & T0 & 94.4 & 3.70 & 89.5 & 94.4 \\
\hline & & $\mathrm{T} 1$ & 88.9 & 3.70 & 88.9 & 88.9 \\
\hline & & $\mathrm{T} 2$ & 88.9 & 3.70 & 88.9 & 88.9 \\
\hline & & $\mathrm{T} 3$ & 88.9 & 1.90 & 94.1 & 88.9 \\
\hline & \multirow{4}{*}{ Holdout } & T0 & 100 & 11.1 & 75.0 & 100 \\
\hline & & $\mathrm{T} 1$ & 60.0 & 0.00 & 100 & 60.0 \\
\hline & & $\mathrm{T} 2$ & 100 & 5.30 & 83.3 & 100 \\
\hline & & $\mathrm{T} 3$ & 87.5 & 0.00 & 100 & 87.5 \\
\hline
\end{tabular}

Table 10. General performance of the LogitBoost classifier

\begin{tabular}{clcc}
\hline Variety & \multicolumn{1}{c}{ Evaluation method } & Correctly classified (\%) & Incorrectly classified (\%) \\
\hline \multirow{2}{*}{ Fhia 21 } & Stratified cross-validation & 90.2778 & 9.7222 \\
& Holdout & 87.5 & 12.5 \\
\hline \multirow{2}{*}{ Orishele } & Stratified cross-validation & 90.2778 & 9.7222 \\
& Holdout & 87.5 & 12.5 \\
\hline
\end{tabular}

Predictions by treatment with holdout method display two tendencies for both varieties (Table 10). Treatment T0 and T2 are highly accurate with no FN samples $(100 \%)$ while T1 and T3 treatments accuracy are low respectively $60 \%$ and $87.5 \%$ with no FP rate.

From models analysis, we can assess that general predictive classification in cross-validation results are good and reflect prediction on each treatment but in testing the models, treatment T1 is overestimated. Anyway, models developed for each cultivar appear acceptable and greatly encouraging even if 10 times tenfold cross-validation should be performed for reliable results and accurate error estimation. 


\section{Conclusion}

In this article, we focus on feasibility for remotely detecting at early stage two plantain varieties inoculated with different Arbuscular Mycorrhizal Fungi. Our results firstly emphasize a new water content indice NWI5 highly significant with Datt5 index at $\mathrm{P}<0.001$. New findings also concern 3 fluorescence features (ANTH, FRF_R, and NBI_R) related to anthocyanin, foliar density and nitrogen content, and 10 others in reflectance spectra (SR5, NDVI3, ratiodRE_703, NWI, NWI4, dNIRmin920_980, min950_970, Carter5, DPI, GI) linked to chlorophyll content, water content, photosynthetic activity and leaf area index. Secondly, we derive predictive multiclass classification models for each cultivar with around $90.3 \%$ and $87.5 \%$ accuracy respectively in stratified cross-validation and holdout evaluation. This demonstrates capability of our fluorescence and reflectance-based instrumentation for quantitatively investigating crop growth under mycorrhizae fertilization. Effective vegetation indices identification in crops specialty as well as rapid pattern recognition of mycorrhizal treatment represent advanced key for developing non-destructive and cost-effective crops monitoring detectors which will more contribute to sustainability in agriculture. Furthermore, we might expect better results in this study using improved version of the LogitBoost classifier. Elaborating a unique model for both plantain varieties could also represent another challenge.

\section{Acknowledgments}

We would like to thank ISP (the International Science Program) for their financial support. We would also like to express our gratitude to all research colleagues from agricultural science and engineering, division of Vegetable and Microbial Biotechnology in National Polytechnic Institute Houphouet-Boigny who provided biological sample and biotechnology expertise that greatly allowed this research.

\section{References}

Agati, G., Foschi, L., Grossi, N., \& Volterrani, M. (2015). In field non-invasive sensing of the nitrogen status in hybrid bermudagrass (Cynodon dactylon $\times$ C. transvaalensis Burtt Davy) by a fluorescence-based method. European Journal of Agronomy, 63, 89-96. http://doi.org/10.1016/j.eja.2014.11.007

Agati, G., Pinelli, P., Cortés Ebner, S., Romani, A., Cartelat, A., \& Cerovic, Z. G. (2005). Nondestructive evaluation of anthocyanins in olive (Olea europaea) fruits by in situ chlorophyll fluorescence spectroscopy. Journal of agricultural and food chemistry, 53(5), 1354-1363. http://doi.org/10.1021/048381d

Arduino - Home. (n.d.). Retrieved November 26, 2015, from https://www.arduino.cc/

Babar, M. A., Reynolds, M. P., van Ginkel, M., Klatt, A. R., Raun, W. R., \& Stone, M. L. (2006). Spectral Reflectance Indices as a Potential Indirect Selection Criteria for Wheat Yield under Irrigation. Crop Science, 46(2), 578. http://doi.org/10.2135/cropsci2005.0059

Baret, F., Guyot, G., \& Major, D. (1988). Coupled Fluorescence and Reflectance Measurements to Improve Crop Productivity Evaluation. In H. K. Lichtenthaler (Eds.), Applications of Chlorophyll Fluorescene in Photosynthesis Research, Stress Physiology, Hydrobiology and Remote Sensing (pp. 319-324). Dordrecht: Springer Netherlands.

Barnes, R., Dhanoa, M., \& Lister, S. (1993). Letter: Correction to the description of Standard Normal Variate (SNV) and De- Trend (DT) ransformations in Practical Spectroscopy with Applications in Food and everage Analysis-2nd Edition. Journal of Near Infrared Spectroscopy, 1(1), 185. http://doi.org/10.1255/jnirs.21

Barton, C. V. ., \& North, P. R. (2001). Remote sensing of canopy light use efficiency using the photochemical reflectance index. Remote Sensing of Environment, 78(3), 264-273. http://doi.org/10.1016/S0034-4257 (01)00224-3

Belanger, M. C., Viau, A. A., Samson, G., \& Chamberland, M. (2005). Determination of a multivariate indicator of nitrogen imbalance (MINI) in potato using reflectance and fluorescence spectroscopy. Agronomy journal, 97(6), 1515-1523. http://doi.org/10.2134/agronj2005.0040

Bewick, V., Cheek, L., \& Ball, J. (2004). Statistics review 9: One-way analysis of variance. Critical Care, 8(2), 130-136. http://doi.org/10.1186/cc2836

Bramley, R. G. V., Le Moigne, M., Evain, S., Ouzman, J., Florin, L., Fadaili, E. M., ... Cerovic, Z. G. (2011). On-the-go sensing of grape berry anthocyanins during commercial harvest: development and prospects: On-the-go sensing of grape anthocyanins. Australian Journal of Grape and Wine Research, 17(3), 316-326. http://doi.org/10.1111/j.1755-0238.2011.00158.x

Bretz, F., Hothorn, T., \& Westfall, P. (2010). Multiple Comparisons Using R. CRC Press. 
Buschmann, C., Langsdorf, G., Lichtenthaler, H.K. (2008) Blue, green, red, and far-red fluorescence signatures of plant tissues, their multicolor fluorescence imaging, and application for agrofood assessment, in: Manuela, Z., (Ed.), Optical Monitoring of Fresh and Processed Agricultural Crops (pp. 272-319). CRC Press.

Cameron, K. C., Di, H. J., \& Moir, J. L. (2013). Nitrogen losses from the soil/plant system: a review. Annals of Applied Biology, 162(2), 145-173. http://doi.org/10.1111/aab.12014

Cartelat, A., Cerovic, Z. G., Goulas, Y., Meyer, S., Lelarge, C., Prioul, J.-L., ... Moya, I. (2005). Optically assessed contents of leaf polyphenolics and chlorophyll as indicators of nitrogen deficiency in wheat (Triticum aestivum L.). Field Crops Research, 91, 35-49. http://doi.org/10.1016/j.fcr.2004.05.002

Carter, G. A. (1994). Ratios of leaf reflectance in narrow wavebands as indicators of plant stress. International Journal of Remote Sensing, 15(3), 697-703. http://doi.org/10.1080/01431169408954109

Cerovic, Z. G., Ounis, A., Cartelat, A., Latouche, G., Goulas, Y., Meyer, S., \& Moya, I. (2002). The use of chlorophyll fluorescence excitation spectra for the non-destructive in situ assessment of UV-absorbing compounds in leaves. Plant, Cell \& Environment, 25(12), 1663-1676. http://doi.org/10.1046/j.1365 $-3040.2002 .00942 . \mathrm{x}$

Chappelle, E. W., Kim, M. S., \& McMurtrey, J. E. I. I. I. (1992). Ratio analysis of reflectance spectra (RARS): an algorithm for the remote estimation of the concentrations of chlorophyll a, chlorophyll $b$ and carotenoids in soybean leaves. Remote Sensing of Environment, 39 (3), 239-247. http://doi.org/10.1016/0034-4257(92) 90089-3

Cvetković, S., Stojanović, M. B., \& Nikolić, S. V. (2015). Multi-channel descriptors and ensemble of Extreme Learning Machines for classification of remote sensing images. Signal Processing: Image Communication, 39, 111-120. http://doi.org/10.1016/j.image.2015.09.004.

Datt, B. (1998). Remote sensing of chlorophyll a, chlorophyll b, chlorophyll a $+\mathrm{b}$ and total carotenoid content in Eucalyptus leaves. Remote Sensing of Environment, 66(2), 111-121. http://doi.org/10.1016/Soo34-4257 (98)00046-7

Declerck, S., Cevos, B., Delvaux, B., \& Plenchette, C. (1994). Growth response of micropropagated banana plants to VAM inoculations. Fruits, 49, 103-109.

Filella, \& Penuelas, J. (1994). The red edge position and shape as indicators of plant chlorophyll content, biomass and hydric status. International Journal of Remote Sensing, 15(7), 1459-1470. http://doi.org/10.1080/0143 1169408954177

Friedman, J., Hastie, T., \& Tibshirani, R. (2000). Special Invited Paper. Additive Logistic Regression: A Statistical View of Boosting. The Annals of Statistics, 28(2), 337-374. http://doi.org/10.1214/aos/1016218223

Gaidashova, S. V., Nsabimana, A., Asten, P. J. A. van, Delvaux, B., Elsen, A., \& Declerck, S. (2013). Impact of arbuscular mycorrhizal fungi on growth of banana genotypes in three different, pasteurized and non-pasteurized soils of Rwanda. In G. Blomme, P. van Asten, \& B. Vanlauwe (Eds.), Banana systems in the humid highlands of sub-Saharan Africa: enhancing resilience and productivity (p. 72-82). Wallingford: CABI.

Gandia, S., Fernández, G., García, J. C., \& Moreno, J. (2004). Retrieval of vegetation biophysical variables from CHRIS/PROBA data in the SPARC campaign. Proceedings of the 2nd CHRISProba Workshop ESAESRIN Frascati Italy 2830. http://earth.esa.int/workshops/chris_proba_04/papers/12_Gandia.pdf

Garbaye, J. (2013). La symbiose mycorhizienne: une association entre les plantes et les champignons. Editions Quae.

Gerdemann, J. W., \& Nicolson, T. H. (1963). Spores of mycorrhizal Endogone species extracted from soil by wet sieving and decanting. Transactions of the British Mycological Society, 46(2), 235-244. http://doi.org/10. 1016/S0007-1536(63)80079-0

Gianinazzi, S. (1981). L'endomycorhizafion contrôlée en agriculture, en horticulture et en arboriculture: problèmes et progrès. In S. Gianinazzi, V. Gianinazzi-Pearson, \& A. Trouvelot (Eds), Les Mycorhizes, Partie Intégrante de la Plante: Biologie et Perspectives d'Utilisation (Les colloques de l'INRA, Vol. 13, pp. 231-241). Paris : INRA.

Hall, M., Frank, E., Holmes, G., Pfahringer, B., Reutemann, P., \& Witten, I. H. (2009). The WEKA Data Mining Software: An Update; ACM SIGKDD Explorations, 11(1), 10. http://doi.org/10.1145/1656274.1656278 
J. Baluja, M. P. D. (2012). Assessment of the spatial variability of grape anthocyanins using a fluorescence sensor. Relationships with vine vigour and yield. Precision Agriculture, 13(4). http://doi.org/10.1007/s11119-012 -9261-x

Jefwa, J. M., Rurangwa, E., Gaidashova, S. V., Kavoo, A. M., Mwashasha, M., Robinson, J., \& Vanlauwe, B. (2013). Indigenous arbuscular mycorrhizal fungi and growth of tissue-cultured banana plantlets under nursery and field conditions in Rwanda. In G. Blomme, P. van Asten, \& B. Vanlauwe (Eds.), Banana systems in the humid highlands of sub-Saharan Africa: enhancing resilience and productivity (pp. 83-92). Wallingford: CABI.

Josep Peñuelas, I. F. (1998). Visible and near-infrared reflectance techniques for diagnosing plant physiological status. Trends in Plant Science, 3(4), 151-156. http://doi.org/10.1016/S1360-1385(98)01213-8

Kanamori, T., \& Takenouchi, T. (2013). Improving Logitboost with prior knowledge. Information Fusion, 14(2), 208-219. http://doi.org/10.1016/j.inffus.2011.11.004

Kassir, L. N. (2014). Environmental Impact of Phosphate Fertilizers and By-Products on Agricultural Soils, in: López-valdez, F. and Fernández-luqueño, F. (Eds.), Fertilizers: Components, Uses in Agriculture and Environmental Impacts (pp. 45-66). Nova Science Publishers, Inc., New York.

Krishnaraj, Y., \& Reddy, C. (2009). Protein Structure Classification Using Machine Learning Methods. In S. Lonardi \& J. Chen (Eds.), Biological Data Mining (Vol. 20093941, pp. 69-87). Chapman and Hall/CRC.

Lichtenthaler, H. K., Wenzel, O., Buschmann, C., \& Gitelson, A. (2006). Plant Stress Detection by Reflectance and Fluorescencea. Annals of the New York Academy of Sciences, 851(1), 271-285. http://doi.org/10. 1111/j.1749-6632.1998.tb09002.x

Misra, A. N., \& Singh, M. M. and R. (2012). Chlorophyll Fluorescence in Plant Biology. http://doi.org/10.5772/ 35111

Moreno, R., Corona, F., Lendasse, A., Graña, M., \& Galvão, L. S. (2014). Extreme learning machines for soybean classification in remote sensing hyperspectral images. Neurocomputing, 128, 207-216. http://doi.org/10. 1016/j.neucom.2013.03.057

Moshou, D., Pantazi, X.-E., Kateris, D., \& Gravalos, I. (2014). Water stress detection based on optical multisensor fusion with a least squares support vector machine classifier. Biosystems Engineering, 117, 15-22. http://doi.org/10.1016/j.biosystemseng.2013.07.008

Mountrakis, G., Im, J., \& Ogole, C. (2011). Support vector machines in remote sensing: A review. ISPRS Journal of Photogrammetry and Remote Sensing, 66(3), 247-259. http://doi.org/10.1016/j.isprsjprs.2010.11.001

Mulla, D. J. (2013). Twenty five years of remote sensing in precision agriculture: Key advances and remaining knowledge gaps. Biosystems Engineering, 114(4), 358-371. http://doi.org/10.1016/j.biosystemseng.2012. 08.009

Murmu, S., \& Biswas, S. (2015). Application of Fuzzy Logic and Neural Network in Crop Classification: A Review. Aquatic Procedia, 4, 1203-1210. http://doi.org/10.1016/j.aqpro.2015.02.153

Nwaga, D., Tenkouano, A., Tomekpe, K., Fogain, R., Kinfack, D. M., Tsané, G., \& Yombo, O. (2011). Multi-functional Properties of Mycorrhizal Fungi for Crop Production: The Case Study of Banana Development and Drought Tolerance. In A. Bationo, B. Waswa, J. M. Okeyo, F. Maina, \& J. M. Kihara (Eds.), Innovations as Key to the Green Revolution in Africa (pp. 523-531). Dordrecht: Springer Netherlands.

Peñuelas, J., Filella, I., Biel, C., Serrano, L., \& Savé, R. (1993). The reflectance at the 950-970 nm region as an indicator of plant water status. International Journal of Remote Sensing, 14(10), 1887-1905. http://doi.org/10. $1080 / 01431169308954010$

Pinheiro, F., \& Gusmo dos Anjos, W. de P. (2014). Optical Sensors Applied in Agricultural Crops. In M. Yasin (Ed.), Optical Sensors - New Developments and Practical Applications. InTech.

R Core Team. (2014). R: A language and environment for statistical computing. R Foundation for Statistical Computing, Vienna, Austria. Retrieved November 26, 2015, from https:/www.R-project.org/.

Sahraoui, A. L. (2013). La Mycorhize à arbuscules : quels bénéfices pour l'homme et son environnement dans un contexte de développement durable? Synthèse: Revue des Sciences et de la Technologie, 26(1), 06-19. 
Smith, R. C.G., Adams, J., Stephens, D. J., \& Hick, P. T. (1995). Forecasting wheat yield in a Mediterranean-type environment from the NOAA satellite. Australian Journal of Agricultural Research, 46(1), 113-125. http://doi.org/10.1071/AR9950113

Sun, P., Reid, M. D., \& Zhou, J. (2014). An improved multiclass LogitBoost using adaptive-one-vs-one. Machine Learning, 97(3), 295-326. http://doi.org/10.1007/s10994-014-5434-3

Tropical Soil Biology and Fertility Institute. (2007). Exploration of Integrated Soil Fertility Management for Banana Production and Marketing in Uganda and Kenya: Arbuscular Mycorrhizal Fungi help Establishment and Production of Tissue Culture Banana. Report to Rockefeller Foundation grant. 2003-2007. TSBF-CIAT, Nairobi.

Weber, O. B. (2014). Biofertilizers with Arbuscular Mycorrhizal Fungi in Agriculture. In Z. M. Solaiman, L. K. Abbott, \& A. Varma (Eds.), Mycorrhizal Fungi: Use in Sustainable Agriculture and Land Restoration (Vol. 41, pp. 45-66). Berlin, Heidelberg: Springer Berlin Heidelberg.

Witten, I. H., Frank, E., \& Hall, M. A. (2011). Data Mining: Practical machine learning tools and techniques, (3rd ed.) Morgan Kaufmann, Publishers Inc. San Fransisco, CA, USA.

Zarco-Tejada, P. J., Pushnik, J. C., Dobrowski, S., Ustin, S. L. (2003). Steady-state chlorophyll a fluorescence detection from canopy derivative reflectance and double-peak red-edge effects. Remote Sensing of Environment, 84(2), 283-294. http://doi.org/10.1016/S0034-4257(02)00113-X

\section{Copyrights}

Copyright for this article is retained by the author(s), with first publication rights granted to the journal.

This is an open-access article distributed under the terms and conditions of the Creative Commons Attribution license (http://creativecommons.org/licenses/by/3.0/). 